\title{
Small Business Policy Index Traction And Movement In Rankings Of States Update: 2000 To 2016
}

\author{
P. K. Shukla, Chapman University, USA \\ Monica P. Shukla, Brandman University, USA
}

\begin{abstract}
Given the volatile economic climate faced in the United States and globally since 2015, there is a desire by politicians in 2016 to increase state economic and business growth. As small businesses are the main driver of business growth in state economies, focus is placed upon the policy environment of a state to encourage state level growth in entrepreneurial activities aimed at small business creation and survival.
\end{abstract}

The Small Business and Entrepreneurship Council an advocacy and research organization dedicated to protecting small business and promoting entrepreneurship has annually prepared a "Small Business Policy Index" that ranks states according to some of the major government-imposed or government-related costs affecting investment, entrepreneurship and business.

This study presents updated results to 2016 from an original 2013 analysis of the rankings of states on the Small Business Policy Index (SBPI) from 2000 to 2016 that focuses upon three categories of states: overall ranking gainer states, those states that are stable in ranking, and overall ranking decliner states, the percentage in each category, and conclusions. The paper also includes a rank correlation analysis of periods of time to measure the extent of traction and mobility in the SBPI state rankings. As states vary by governor length of years in the ir governor term and also by term limits or not on governorterms allowed there is an analysis of impact of governoryears of term on changes in SBPI ranking and an analysis of impact of governor term limits on changes in SBPI ranking.

Keywords: Small Businesses; Small Business Policy Index; Promoting Entrepreneurship; Government Policy

\section{INTRODUCTION}

iven the volatile economic climate faced domestically in the United States and globally since 2015, there is a desire by politicians in 2016 to increase state economic and business growth. Business growth at the state level is good for increasing state employment, increasing state household/business income, increasing state level household consumption, and in raising state tax revenue. Given the fact that small businesses are the main driver of business growth in state economies, focus should be placed upon the policy environment of a state to encourage state level growth in entrepreneurial activities aimed at small business creation and small business survival.

During state elections, state politicians often claim that they are in favor of change, reform, and in helping to stimulate business and entrepreneurs hip growth once elected. If such political efforts were effective at the state level, one would expect that a state should improve in its ranking on rankings that examine state level small business supportive policy levels over various extended periods of time.

"The Small Business and Entrepreneurship Council (SBE Council) is a 501c(4) advocacy, research, training and networking organization dedicated to protecting small business and promoting entrepreneurship. The SBE Council works to educate elected officials, policymakers, business leaders and the public about key policies that enable business start-up and growth. Through advocacy, research, media outreach, training and education, SBE Council members and staff convey the importance of entrepreneurship to job creation, innovation, economic growth and U.S. 
competitiveness. The SBE Council is viewed as one of the most powerful and effective organizations dedicated to protecting small business, and promoting entrepreneurship" (“About us,” n.d., para. 1-2).

Since 1995, the SBE Council has annually (except for 2015 which was skipped) prepared a "Small Business Survival Index" (renamed "Small Business Policy Index" in 2016) in which the report ranks the 50 states and the District of Columbia according to some of the major government-imposed or government-related costs affecting investment, entrepreneurship and business. The Small Business Policy Index ("SBPI") ranks the states according to their policy climates for entrepreneurship. The Small Business \& Entrepreneurship Council's "Small Business Policy Index 2016" (previously called SBSI) ranks the states from best to worst on policy measures and costs impacting entrepreneurship and small business growth. The 2016 edition of the Index pulls together 50 different measures, and combines those into one score that allows the 50 states to be compared and ranked (Keating, 2016).

"Of the 50 measures of the 2016 Small Business Policy Index, 25 are taxes or tax related, 18 relate to rules and regulations, five deal with government spending and debt issues, with the two remaining measures gauging the effectiveness of important government undertakings" (Keating, 2016, p. 5).

This study presents the updated 2016 results from a prior 2013 conference paper presentation "Small Business Survival Index Traction and Movement In Rankings of States: 2000 TO 2013," paper presented at the 2013 Academic \& Business Research Institute International Conference, October, 2013 in Las Vegas, Nevada (Shukla \& Shukla, 2013) and a prior published article (Shukla \& Shukla, 2014) on the Small Business Policy Index from 2000 to 2016 focuses upon three categories of states: those that remained relatively stable in their rank (defined as same rank or $+/-$ a slight change in ranking: +3 to -3 overall change in ranking from 2000 to 2016), those who significantly improved in their ranking (a significant improvement is defined as a +4 or more increase in overall ranking from 2000 to 2016), and those who significantly decreased in their ranking (a significant decrease is defined as a -4 or more decrease in overall ranking from 2000 to 2016). Table 1 displays a rank ordered listing of the 50 states (excluding the District of Columbia) based upon their overall change in SBPI rank from 2000 to 2016 and also displays the yearly rank of each state from 2000 to 2016.

\section{Changes In Overall SBPI Ranking}

The paper identifies the nominal number in each of the three categories: Overall gainer states, those states that are stable, and Overall decliner states, the percentage in each category, and overall conclusions. The paper also includes a rank correlation analysis of various periods of time to measure the extent of traction (little to no change in ranking) and mobility in the SBPI state rankings from 2000 to 2016. As states vary by governor length of years in their governor term and also by term limits or not on governor terms allowed there is an analys is of impact of governor years of term on changes in SBPI ranking and an analys is of impact of governor term limits on changes in SBPI ranking.

Table 1 displays the changes in overall SBPI ranking of each s tate from 2000 to 2016 . The table displays the following results on the breakdown of states into the three categories based upon overall change in rank over the sixteen-year period of 2000 to 2016 :

1. 12 states significant gainers (+ 4 or more increase 2000 to 2016); see Table 1 for State names

2. 18 states no significant change (+ 3 to -3 change 2000 to 2016); see Table 1 for State names

3. 20 states significant decliners (- 4 or more decrease 2000 to 2016); see Table 1 for State names

The results for the 50 states show that $64 \%$ of the states display significant change and that movement is possible both upward (12 out of 50 states gainers: $24 \%$ ) and downward (20 out of 50 states decliners: $40 \%$ ). Despite the mobility displayed, a high percentage value remains at $36 \%$ of the states displaying no significant change from 2000 to 2016 (18 out of 50 states with an overall change in ranking on the SBPI no greater than a +3 gain or no more than - 3 decline). 
Table 1. Changes in Overall SBPI State Rankings From 2000 to 2016

\begin{tabular}{|c|c|c|c|c|c|c|c|c|}
\hline 2016 & 2008 & 2007 & 2000 & State & $16 \mathrm{v} .00$ & Change & 16 v. 08 & 07 v. 00 \\
\hline 9 & 18 & 29 & 46 & Ohio & 37 & 1 & 9 & 17 \\
\hline 26 & 29 & 25 & 48 & New Mexico & 22 & 2 & 3 & 23 \\
\hline 19 & 39 & 39 & 41 & North Carolina & 22 & 3 & 20 & 2 \\
\hline 13 & 15 & 18 & 33 & Utah & 20 & 4 & 2 & 15 \\
\hline 8 & 13 & 15 & 23 & Arizona & 15 & 5 & 5 & 8 \\
\hline 21 & 31 & 30 & 36 & Kansas & 15 & 6 & 10 & 6 \\
\hline 31 & 33 & 35 & 45 & Montana & 14 & 7 & 2 & 10 \\
\hline 20 & 21 & 21 & 31 & Oklahoma & 11 & 8 & 1 & 10 \\
\hline 39 & 47 & 48 & 49 & Rhode Island & 10 & 9 & 8 & 1 \\
\hline 14 & 22 & 20 & 20 & North Dakota & 6 & 10 & 8 & 0 \\
\hline 11 & 10 & 11 & 16 & Colorado & 5 & 11 & -1 & 5 \\
\hline 46 & 41 & 42 & 50 & Hawaii & 4 & 12 & -5 & 8 \\
\hline 18 & 12 & 12 & 21 & Georgia & 3 & 13 & -6 & 9 \\
\hline 29 & 35 & 36 & 32 & Idaho & 3 & 14 & 6 & -4 \\
\hline 10 & 20 & 14 & 13 & Indiana & 3 & 15 & 10 & -1 \\
\hline 2 & 6 & 7 & 5 & Texas & 3 & 16 & 4 & -2 \\
\hline 15 & 9 & 9 & 17 & Virginia & 2 & 17 & -6 & 8 \\
\hline 7 & 8 & 10 & 8 & Alabama & 1 & 18 & 1 & -2 \\
\hline 5 & 4 & 5 & 6 & Florida & 1 & 19 & -1 & 1 \\
\hline 41 & 48 & 47 & 42 & Maine & 1 & 20 & 7 & -5 \\
\hline 1 & 2 & 2 & 2 & Nevada & 1 & 21 & 1 & 0 \\
\hline 43 & 32 & 34 & 44 & Oregon & 1 & 22 & -11 & 10 \\
\hline 6 & 5 & 4 & 7 & Washington & 1 & 23 & -1 & 3 \\
\hline 47 & 46 & 45 & 47 & Minnesota & 0 & 24 & -1 & 2 \\
\hline 28 & 40 & 40 & 28 & West Virginia & 0 & 25 & 12 & -12 \\
\hline 16 & 7 & 8 & 15 & South Carolina & -1 & 26 & -9 & 7 \\
\hline 4 & 3 & 3 & 3 & Wy oming & -1 & 27 & -1 & 0 \\
\hline 3 & 1 & 1 & 1 & South Dakota & -2 & 28 & -2 & 0 \\
\hline 37 & 30 & 27 & 34 & Arkansas & -3 & 29 & -7 & 7 \\
\hline 12 & 19 & 6 & 9 & Michigan & -3 & 30 & 7 & 3 \\
\hline 42 & 42 & 41 & 38 & Iowa & -4 & 31 & 0 & -3 \\
\hline 22 & 27 & 31 & 18 & Louisiana & -4 & 32 & 5 & -13 \\
\hline 33 & 26 & 33 & 29 & Wisconsin & -4 & 33 & -7 & -4 \\
\hline 49 & 50 & 50 & 43 & New Jersey & -6 & 34 & 1 & -7 \\
\hline 30 & 25 & 24 & 24 & Pennsylvania & -6 & 35 & -5 & 0 \\
\hline 17 & 17 & 16 & 10 & Mississippi & -7 & 36 & 0 & -6 \\
\hline 27 & 24 & 26 & 19 & Illinois & -8 & 37 & -3 & -7 \\
\hline 35 & 44 & 44 & 27 & Massachusetts & -8 & 38 & 9 & -17 \\
\hline 38 & 36 & 37 & 30 & Nebraska & -8 & 39 & -2 & -7 \\
\hline 48 & 45 & 46 & 40 & New York & -8 & 40 & -3 & -6 \\
\hline 45 & 43 & 43 & 37 & Vermont & -8 & 41 & -2 & -6 \\
\hline 44 & 37 & 38 & 35 & Connecticut & -9 & 42 & -7 & -3 \\
\hline 34 & 23 & 22 & 25 & Kentucky & -9 & 43 & -11 & 3 \\
\hline 36 & 34 & 32 & 26 & Delaware & -10 & 44 & -2 & -6 \\
\hline 24 & 14 & 19 & 14 & Missouri & -10 & 45 & -10 & -5 \\
\hline 50 & 49 & 49 & 39 & California & -11 & 46 & -1 & -10 \\
\hline 23 & 11 & 13 & 11 & Tennessee & -12 & 47 & -12 & -2 \\
\hline 25 & 16 & 17 & 12 & Alaska & -13 & 48 & -9 & -5 \\
\hline 40 & 38 & 28 & 22 & Mary land & -18 & 49 & -2 & -6 \\
\hline 32 & 28 & 23 & 4 & New Hampshire & -28 & 50 & -4 & -19 \\
\hline
\end{tabular}

Sou rce: Annual data aggregated from SBE Council.(n.d.). SBE council research \& publications. Retrieved from http://sbecouncil.org/sbe-councilresearch-publications/ 
Although some level of change is displayed as possible at improving state ranking on the SBPI over sixteen years, sustained gains over two different long term time periods (the time period of 2000 to 2007 followed by the time period of 2008 to 2016) is even more difficult. Only 3 states out of $50(6 \%)$ showed sustained gains $(+4$ or more gain in rank during both time periods of 2000 to 2007 and 2008 to 2016). The majority of states, 43 out of 50 states (86 \%) displayed no sustained change during both time periods. Again, the data displays that downward mobility in ranking is more common than upward mobility as 4 states out of $50(8 \%)$ states displayed sustained decline (- 4 or more decrease in rank both periods 2000 to 2007 and 2008 to 2016).

One explanation for the high percentage of states (86\%) displaying no sustained gains or sustained declines, is that many of the 43 states had offset gains and losses during the two time periods examined. 20 out of the 50 states (40\%) had offsetting rank gains during 2000 to 2007 followed by rank losses during 2008 to 2016 or rank losses during 2000 to 2007 followed by rank gains during 2008 to 2016. The data indicates that changes in state rank occur due to state level actions such as governor and state legis lature business tax policy changes, but that these changes are often offset possibly by newly elected governors or newly elected state legislators.

In some particular case examples of states, the offsets are very dramatic:

4. Oregon: A + 10 gain in rank from 2000 to 2007 offset during 2008 to 2016 with a rank decline of - 11 .

5. Massachusetts: A - 17 loss in rank from 2000 to 2007 offset during 2008 to 2016 with a rank gain of + 9 .

6. West Virginia: A - 12 loss in rank from 2000 to 2007 offset during 2008 to 2016 with a rank gain of + 12.

\section{Rank Correlation Analysis Of Different Time Durations:}

A rank correlation analysis was performed on the SBPI state rankings of 2016 compared with various durations of time periods of gap in years up to 2016. The following rank correlation analysis displayed in Table 2 supports the conclusion that there is a high level of traction with little mobility in ranking over time periods that varied from two years to sixteen years. All of the rank correlations range from 0.70 to 0.98 . The data indicates that little change in rank is possible during one governor term and that very little change in rank is possible during one state legis lative term as the rank correlations range from 0.93 to 0.98 for a two year to four year duration.

Table 2. Rank Correlation Analy sis Of SBSI State Rankings Over Different Time Durations

\begin{tabular}{l|l|l}
\hline 0.9846 & correlation 2016 and 2014 & 2 year change \\
\hline 0.9282 & correlation 2016 and 2013 & 3 year change \\
\hline 0.9480 & correlation 2016 and 2012 & 4 ear change \\
\hline 0.8933 & correlation 2016 and 2011 & 5 year change \\
\hline 0.9140 & correlation 2016 and 2010 & 6 year change \\
\hline 0.9145 & correlation 2016 and 2009 & y ear change \\
\hline 0.8928 & correlation 2016 and 2008 & 8 year change \\
\hline 0.8764 & correlation 2016 and 2007 & 9 year change \\
\hline 0.8044 & correlation 2016 and 2006 & 10 year change \\
\hline 0.7830 & correlation 2016 and 2005 & 11 year change \\
\hline 0.7895 & correlation 2016 and 2004 & 12 year change \\
\hline 0.7481 & correlation 2016 and 2003 & 13 year change \\
\hline 0.7428 & correlation 2016 and 2002 & 14 year change \\
\hline 0.7209 & correlation 2016 and 2001 & 15 year change \\
\hline & correlation 2016 and 2000 & 16 year change
\end{tabular}

\section{Impact Of Governor Years Of Term On Changes In SBPI Ranking}

As of 2016, all states except New Hampshire (2 year term) and Vermont (2 year term) have four year term for Governors. Both Vermont and New Hampshire are in the category of significant decliners (Vermont ranked 41st out of 50 states with an overall 16 year decline of - 8 and New Hampshire ranked $50^{\text {th }}$ out of 50 states with a decline of 28) and New Hampshire is in the sub-category of sustained decliners (decline of - 1 or greater in both time periods 
2000 to 2007 and 2008 to 2016); this may lead support to the notion that a governor aiming at improving state ranking on the small business survivability index needs more than just a two year term.

\section{Impact Of Governor Term Limits On Changes In SBPI Ranking}

As of 2016, governors of 36 states are subject to various term limits, while the governors of 14 states may serve an unlimited number of times. The Governors of New Hampshire and Vermont may serve unlimited two-year terms. The governors in the following states may serve unlimited four-year terms: Connecticut, Idaho, Illinois, Iowa, Massachusetts, Minnesota, New York, North Dakota, Texas, Utah, Washington, Wisconsin. Table 3 displays for the states with unlimited governor terms, the state's rank ordered SBPI rank change from 2000 to 2016 in table 1 and the nominal change (+ or -).

Table 3. Impact of Governor Terms Limits on Changes in SBPI Ranking

\begin{tabular}{|c|c|c|c|}
\hline & Decliners: & Stable: & Gainers: \\
\hline New Hampshire (2 yr unlimited terms) & $50^{\text {th }}-28$ & & \\
\hline Vermont (2 yr unlimited terms) & 41 st -8 & & \\
\hline Connecticut (4 yr unlimited terms) & $42 n d-9$ & & \\
\hline$\underline{\text { Idaho }}$ (4 yr unlimited terms) & & 14 th +3 & \\
\hline Illinois (4 yr unlimited terms) & $37^{\text {th }}-8$ & & \\
\hline$\overline{\text { Iowa }}$ (4 yr unlimited terms) & 31 st -4 & & \\
\hline Massachusetts (4 yr unlimited terms) & 38 th -8 & & \\
\hline Minnesota (4 yr unlimited terms) & & 24 th +0 & \\
\hline New York (4 yr unlimited terms) & 40 th -8 & & \\
\hline North Dakota (4 yr unlimited terms) & & & $10^{\text {th }}+6$ \\
\hline$\underline{\text { Texas (4 yr unlimited terms) }}$ & & $16^{\text {फ் }}+3$ & \\
\hline$\underline{\mathrm{Utah}}$ (4 yr unlimited terms) & & & 4 th +20 \\
\hline Washington (4 yr unlimited terms) & & $23 \mathrm{rd}+1$ & \\
\hline Wisconsin (4 yr unlimited terms) & $33 r d-4$ & & \\
\hline
\end{tabular}

The state listing breakdown in Table 3 supports the idea of term limits for governors as only 2 out of 14 states showed significant gains in rank over the 16 year period of 2000 to 2016 in the small business policy index whereas 8 out of the 14 states with unlimited terms for governors showed significant declines over the 16 year period of 2000 to 2016.

\section{CONCLUSIONS AND AREAS FOR FUTURE RESEARCH}

Despite political candidate rhetoric about promising to bring about business and economic climate improvements by being change agents, the reality is that there is little if any sustained change displayed in state rankings over the term or terms of most state governors during the time period examined of 2000 to 2016. Upward mobility in SBPI ranking is displayed as hard to achieve and sustained upward mobility in SBSI ranking over two consecutive eight year periods of time is even more difficult.

Future research can focus upon a more detailed analysis of those few states with sustained upward mobility over two consecutive eight year periods of time. It will be interesting to see if these few states used similar paths of policy reform to improve their state rankings or if multiple paths of policy reform were displayed.

\section{AUTHOR BIOGRAPHIES}

Dr. P. K. Shukla is an Associate Professor of Management at the Argyros School of Business and Economics at Chapman University. He has served previously as Director of the Leatherby Center for Entreprenurship and as Vice Chancellor for Entrepreneurship at Chapman University. He has consulted to busines ses and has served on boards of directors of organizations in addition to serving on the editorial review board of academic journals. His Ph. D. is from the University of California, Los Angeles and he has a Master's of Science Degree in Business Administration from the University of Southern California. 
Dr. Monica Shukla is Associate Dean of the School of Business and Professional Studies at Brandman University in Irvine, California. She received her Ph.D. from Chapman University and her dis sertation focused upon an examination of best practices in the use of social media by higher education institutions including an analysis of return on investment measurement approaches. She has served in managerial positions in higher education and has entrepreneurial experience with her own consulting firm. She has Master's Degrees in Human Resources Management and also in Organizational Leadership. She also has an Executive Certificate in Non-Profit Leadership.

\section{REFERENCES}

Keating, R. J. (2016). Small business policy index 2016: Ranking the states on policy measures and costs impacting entrepreneurship and small business growth $\left(20^{\text {th }}\right.$ ed.). Retrieved from http://sbecouncil.org/wpcontent/uploads/2016/02/SBPIndex2016SBECouncil.pdf

SBE Council. (n.d.). About us. Retrieved from http://sbecouncil.org/about-us/

SBE Council. (n.d.). SBE council research \& publications. Retrieved from http://sbecouncil.org/sbe-council-researchpublications/

Shukla, P. K.; \& Shukla, M.P. (2014). Small business survival index traction and movement in rankings of states (2000-2013). Journal of Business \& Economics Research, 12(2), 153-158. doi:http://dx.doi.org/10.19030/jber.v12i2.8529

Shukla, P. K.; \& Shukla, M.P. (2013, October). Small business survival index traction and movement in rankings of states: 2000 to 2013. Paper presented at the 2013 Academic \& Business Research Institute International Conference, Las Vegas, Nevada. Retrieved from http://www.aabri.com/LV2013Manuscripts/LV13019.pdf 